\title{
Nodular lymphocyte predominance Hodgkin lymphoma of the parotid gland: a case report
}

Carlos Augusto Ferreira Alves ${ }^{a}$, Marcia Maria de Gouveiaa, Adalmir Gonzaga dos Santos Queiroz ${ }^{a}$, Mariana Aparecida Brozoski ${ }^{\mathrm{a}}$, José Pinhata Otoch ${ }^{\mathrm{b}}$, Paulo Sérgio Martins de Alcântara ${ }^{\mathrm{b}}$, Patrícia Picciarelli de Lima $^{c}$, Aloísio Felipe-Silvac

Alves CAF, Gouveia MM, Queiroz AGS, et al. Nodular lymphocyte predominance Hodgkin lymphoma of the parotid gland: a case report. Autopsy Case Rep [Internet]. 2012;2(1):43-47. http://dx.doi.org/10.4322/acr.2012.007

\section{ABSTRACT}

The parotid is the most frequent site of primary salivary gland tumors. Lymphomas represent 0.2 to $0.8 \%$ of all malignant parotid tumors. Primary Hodgkin lymphoma of the parotid gland is rare with few cases reported in literature. The nodular lymphocyte predominance Hodgkin lymphoma (HL) is considered a particular clinical and histopathological subtype of $\mathrm{HL}$. It has never been reported in the parotid gland since its incorporation in the 2001 World Health Organization Classification. The authors describe a case of a 32-year-old male who sought medical attention because of a one-year history of right cheek enlargement. A parotid nodule was submitted to a fine needle aspiration biopsy which disclosed a suspected lymphoproliferative disorder. A surgical dissection of the parotid gland was performed and an enlarged intraparotid lymph node measuring $4 \mathrm{~cm}$ in its longest axis was excised, preserving the parotid gland integrity as well as the facial nerve. The pathological examination disclosed the diagnosis of nodular lymphocyte predominance Hodgkin lymphoma in this lymph node within the parotid gland. The treatment was completed with local radiotherapy and the 5-year follow up was uneventful.

Keywords: Parotid gland; Adult Hodgkin lymphoma surgery; Fine needle biopsy.

\section{CASE REPORT}

A 32-year-old caucasian male patient sought the Surgery department at the University Hospital of the University of São Paulo, complaining of right cheek swelling for about one year (Figure 1A). There were no other symptoms.

On clinical examination there was a nodule in the right parotid gland region, with up to $3 \mathrm{~cm}$ in its longest axis, with well-defined limits. On palpation it was painless and hard, suggesting a parotid pleomorphic adenoma as first diagnostic hypothesis. There were no other signals on physical examination. The ultrasonography revealed a $3.0 \mathrm{~cm}$ hypoechoic nodular structure inside the parotid gland.

The patient was submitted to a fine needle aspiration (FNA) biopsy and the cytologic analysis

\footnotetext{
a Department of Dentistry - Hospital Universitário - Universidade de São Paulo, São Paulo/SP - Brazil.

b Department of Surgery - Hospital Universitário - Universidade de São Paulo, São Paulo/SP - Brazil.

${ }^{c}$ Anatomic Pathology Service - Hospital Universitário - Universidade de São Paulo, São Paulo/SP - Brazil.
}

Copyright $\odot 2012$ Autopsy and Case Reports - This is an Open Access article distributed of terms of the Creative Commons Attribution NonCommercial License (http://creativecommons.org/licenses/by/3.0/) which permits unrestricted non-commercial use, distribution, and reproduction in any médium provided article is properly cited. 
revealed scarce cells with large multilobed and convoluted nuclei, with nuclear membrane irregularity and macronucleoli, highly suggestive of Hodgkin lymphoma (HL) diagnostic cells (Figure 2A). These cells were present in a background containing a large number of small polymorphic lymphocytes, frequent eosinophils (Figure 2B) and rare aggregates of histiocytes in an outline of granulomas. Typical findings of reactive lymphoid hyperplasia like lymph-histiocytic aggregates or tangible body macrophages were not detected. FNA findings were interpreted as suspicious for lymphoproliferative disorder demanding surgical excisional biopsy for precise diagnosis definition.

The right parotid gland was operated on by trans-node excision in order to preserve the facial nerve (Figures 1B,C). The excisional biopsy of the intraparotid lymph node was performed and the whole material was sent for pathological analysis. Gross examination revealed a $4.0 \times 3.0 \times 2.5 \mathrm{~cm}$ nodular tumor covered by a smooth and translucent capsule. On sectioning surface the tissue showed a light brown color, smooth appearance and elastic consistency (Figure 1D).
The histological analysis showed a diffuse and vaguely multinodular lymphoid proliferation. Large cells with the same characteristics observed in the FNA were distributed in a nodular background composed of small lymphocytes and numerous reactive granulomas formed by epithelioid histiocytes (Figures 3A,B). Special stains for microorganisms were negative. On immunohistochemistry analysis, the large cells were CD20 positive (Figure 4A), CD15 negative, CD30 negative, CD10 negative, EMA negative and CD3 negative.

These morphological and immunohistochemical findings were consistent with lymphocytic and histiocytic (L\&H) diagnostic cells of a nodular lymphocyte predominance Hodgkin Lymphoma (NLPHL). Around these cells, there was a crown of reactive $\mathrm{CD} 3+$ and $\mathrm{CD} 57+\mathrm{T}$ lymphocytes. Small lymphocytes without atypia in the background were mainly CD20+. The reactive histiocytes and granulomas were CD68+ (Figure 4B) and a network of expanded follicular dendritic cells within the nodules was demonstrated by the positivity for CD21. Altogether, these findings were consistent with a NLPHL of a lymph node within the parotid gland.

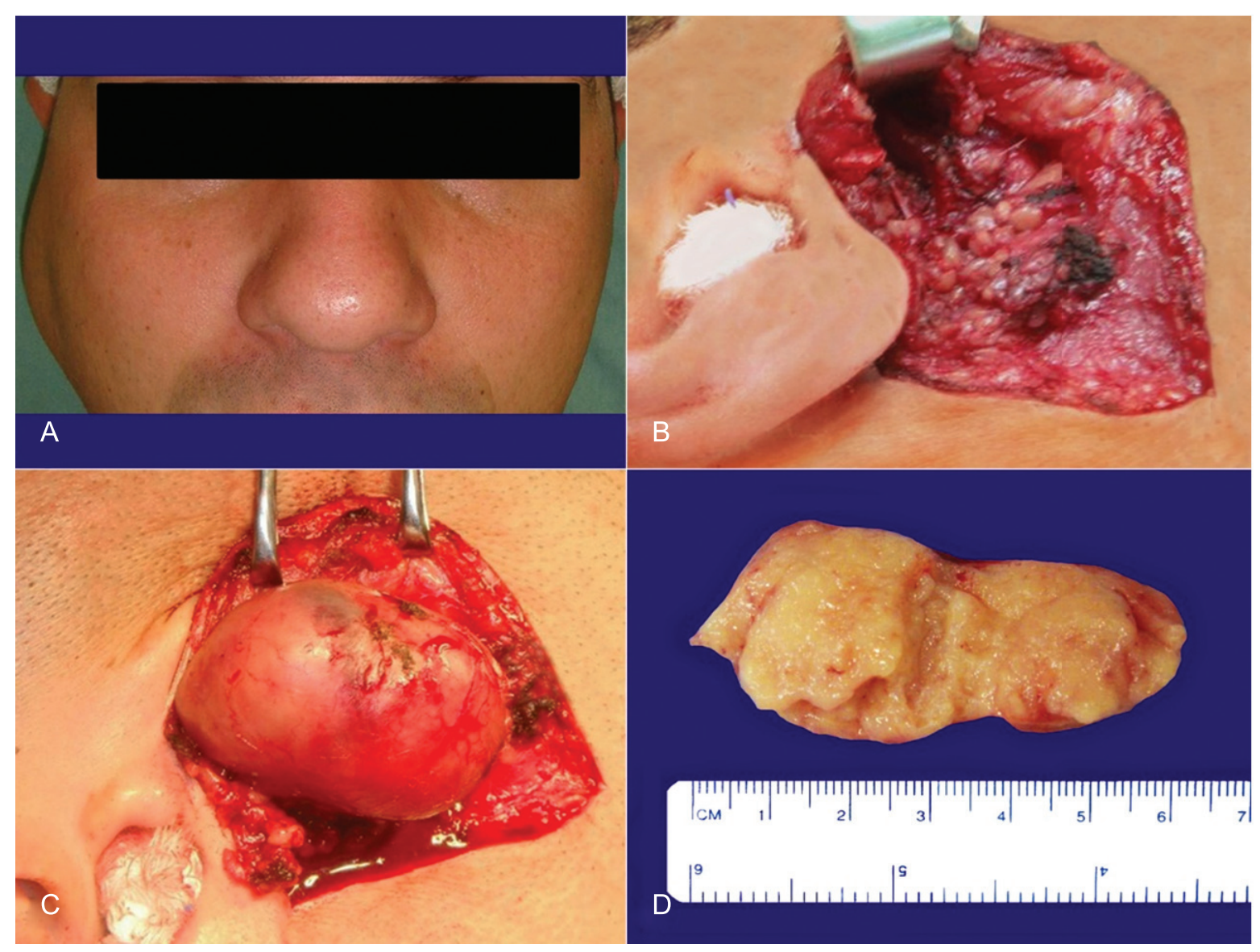

Figure 1 - A- Asymmetric enlargement of the right cheek; B and C- Surgical exeresis of the intraparotid lymph node; D- Sectioning surface of the lymph node. 
Surgical treatment was complemented by adjuvant radiotherapy. The patient is in remission in a current 5-year follow-up with periodic clinical and imaging controls.

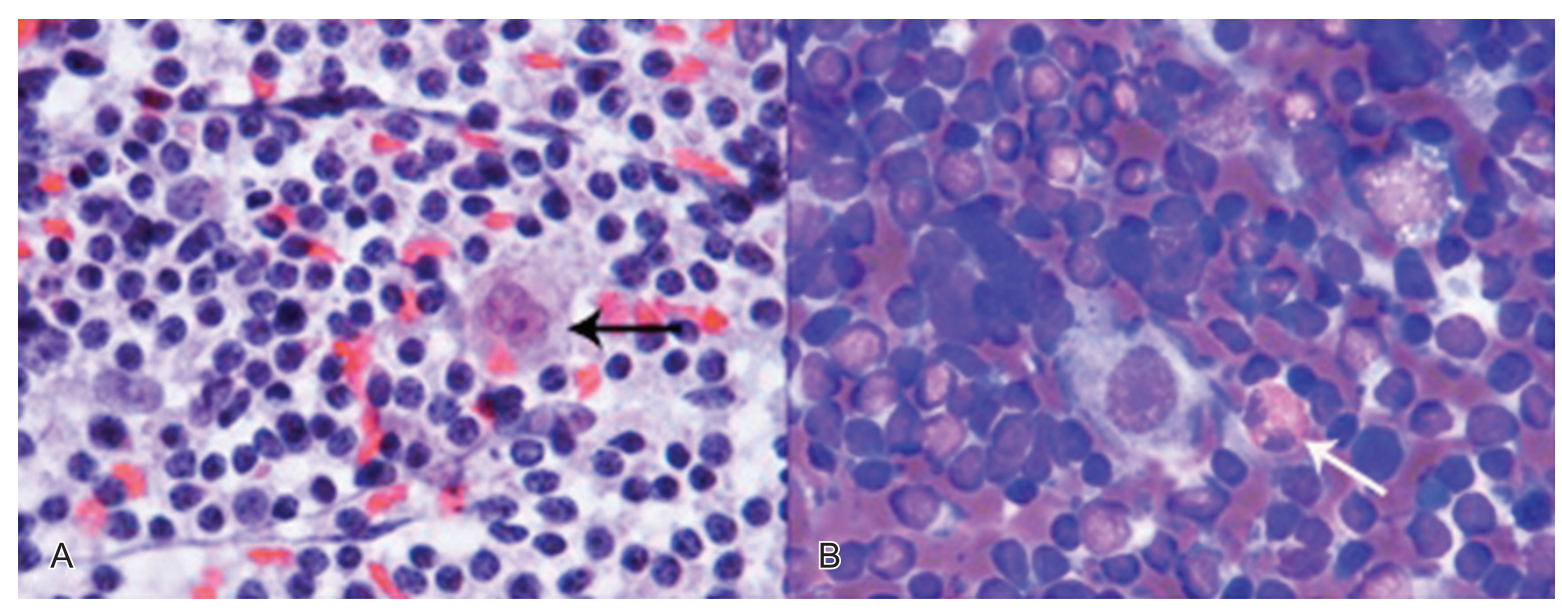

Figure 2-Photomicrography - Cytologic examination of the intraparotid lymph node aspirate. A- (Papanicolau stain, 400X) large cells (black arrow) with irregular enlarged nuclei and macronucleoli; B- (Dry panotic stain, 1000X) Large atypical cell in a background of small lymphocytes and eosinophils (white arrow).

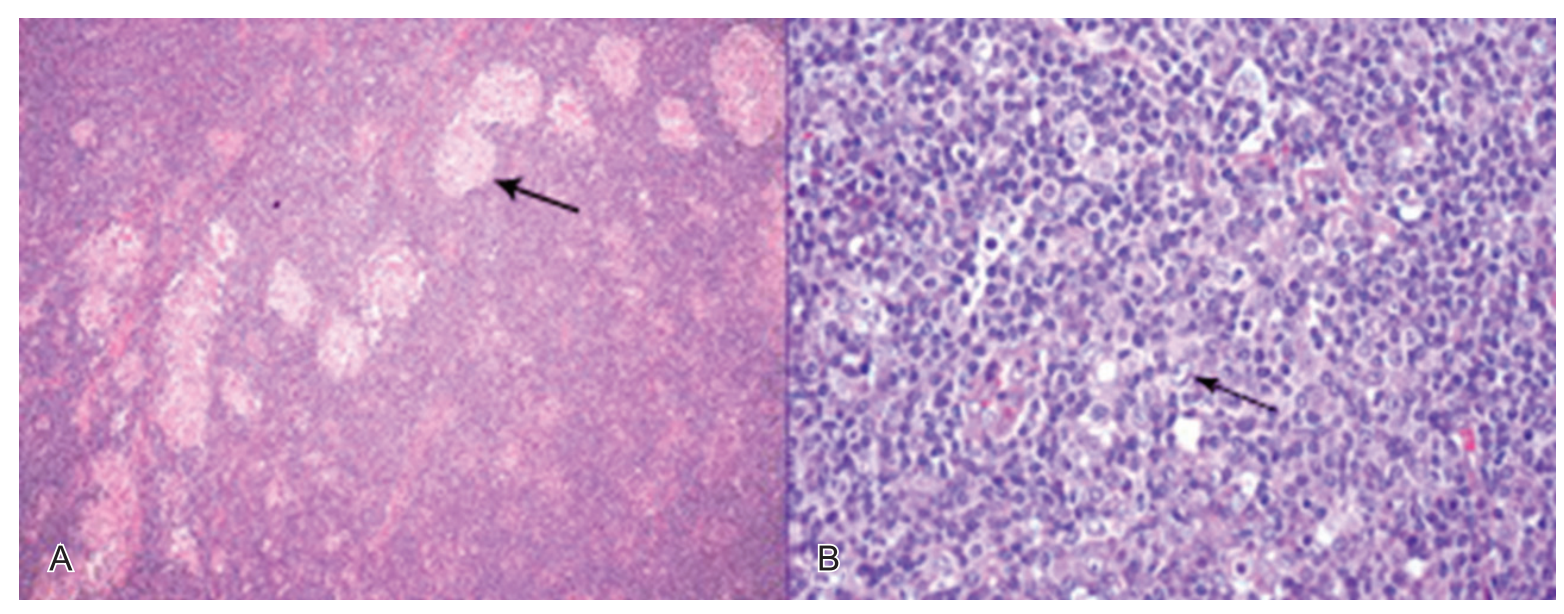

Figure 3 - Photomicrography - Histologic examination of the intraparotid lymph node. (hematoxilin \& eosin) A- Panoramic view (100X) Diffuse, imprecise multinodular lymphoid proliferation, with reactive granulomas (arrow); B- (400X) Large atypical cells (arrow) in a background rich in small lymphocytes.

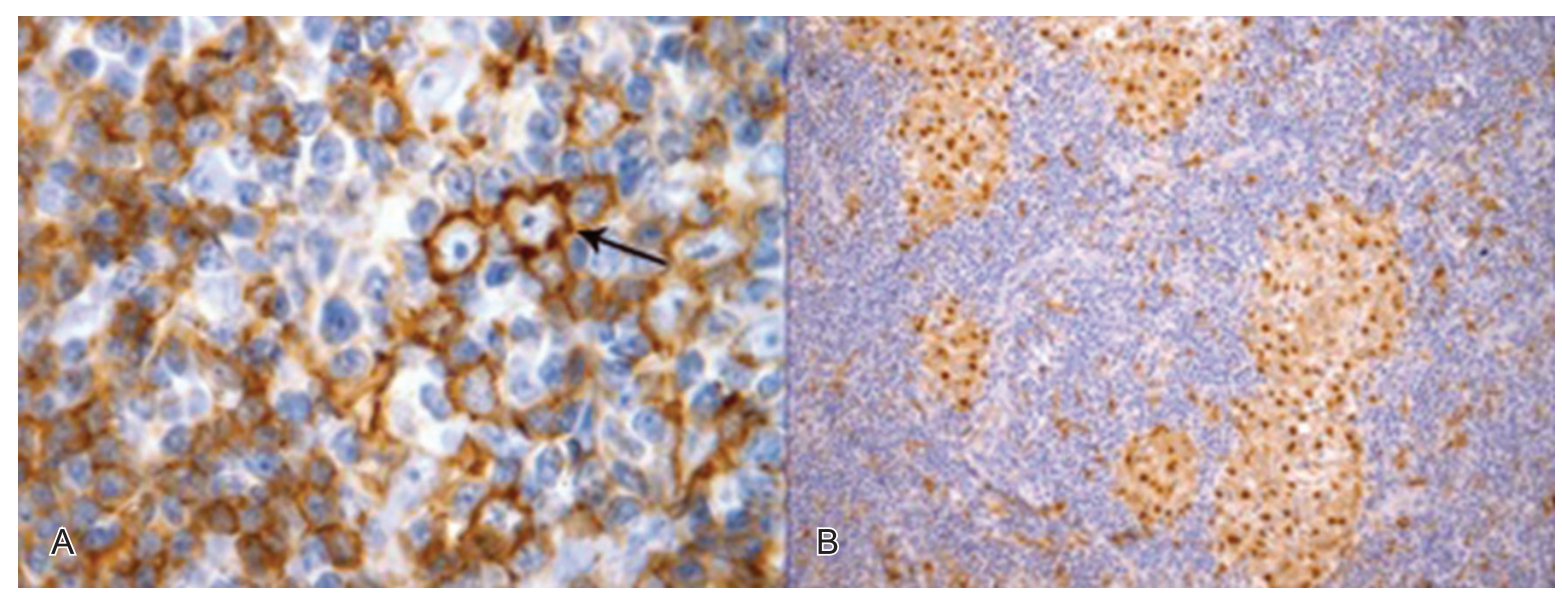

Figure 4 - Photomicrography - Immunohistochemistry. A- (400X) positivity for CD20 in the L\&H cell (arrow); B- CD68+ reactive granulomas. 


\section{DISCUSSION}

Hodgkin's lymphoma is a malignant lymphoproliferative disorder defined in terms of histology and immunophenotype. It usually affects the lymph nodes of the cervical region of young adults in most cases. ${ }^{1}$

Lymphomas within the parotid gland are rare. Their incidence accounts for 0.2 to $0.8 \%$ of all malignant parotid tumors. ${ }^{2}$ The parotid gland is more commonly affected when compared to the submandibular and sublingual glands. Salivary glands lymphomas occur most frequently in women with Sjögren's syndrome. ${ }^{3}$ In the parotid gland, the most common type of lymphoma is non-Hodgkin lymphoma. ${ }^{2,4}$

The NLPHL is considered a particular (nonclassical) clinical and histopathological subtype of $\mathrm{HL} .{ }^{1}$ The classic form of $\mathrm{HL}$ comprises the other four histopathological categories: nodular sclerosis, mixed cellularity, lymphocyte depletion and the lymphocyte-rich classic HL. ${ }^{1}$

Approximately 3 to $5 \%$ of head and neck tumors are lymphomas, which can be classified as $\mathrm{HL}$ or non-Hodgkin lymphomas. ${ }^{5,6}$

$\mathrm{HL}$ is responsible for about $14 \%$ of all lymphomas. ${ }^{5} \mathrm{NLPHL}$ corresponds to $5-10 \%$ of all $\mathrm{HL}$. When compared to classic HL, NLPHL is more frequent in males $(70 \%)$ with the involvement of peripheral lymph nodes. Symptoms such as fever, weight loss and night sweats (B symptoms) are observed in less than $20 \%$ of the affected patients. Additionally, the clinical course is usually indolent, with late relapses. ${ }^{1}$

NLPHL is distinguished from the classical $\mathrm{HL}$ by histological, genetic and immunophenotypic features. The scarce malignant cells in NLPHL are of the lymphocytic and histiocytic (L\&H) type, morphologically different from the ReedStenberg cell of the classic HL. L\&H cells are arranged in a reactive background of small $B$ and $T$ lymphocytes. They express B-lymphocytes markers (CD20, CD79a) and epithelial membrane antigen (EMA), but not CD30 or CD15, in contrast to the classic HL. ${ }^{1,7}$ Clinical presentation in the head and neck may vary from nodal and/or extranodal sites. ${ }^{8}$

Primary $\mathrm{HL}$ in the parotid gland is a rare entity with very few cases reported in the literature..$^{9,10}$ In fact, in order to be considered a primary parotid tumor, gland involvement must be the first clinical manifestation of lymphoma. $\mathrm{HL}$ is usually not suspected in the conventional approach of a parotid tumor. In a review of primary lymphomas of the parotid gland, Yencha et al. (2002) described the "lymphocyte predominance subtype" (classic $\mathrm{HL}$ ) as the most common, accounting for $40 \%$ of cases. ${ }^{10}$ However, as the NLPHL entered the WHO classification only in 2001 , possibly some of the previous cases described as lymphocyte-rich/ lymphocyte predominance classical $\mathrm{HL}$ would be now reclassified as NLPHL. In fact, in Yencha et al. series, immunophenotypic profiles of $\mathrm{HL}$ cases were not shown. We did not find any report in the literature of NLPHL located in the parotid gland. Although NLPHL was first described in the 1980's, it was only incorporated into the $\mathrm{WHO}$ classification in 2001. It is likely that at least a few cases previously classified as primary lymphocyte-rich/lymphocyte predominance classic HL of the parotid gland would be reclassified as NLPHL nowadays.

The access of major salivary glands is relatively easy, and therefore these glands are excellent targets for FNA biopsy. ${ }^{11}$ This procedure is often indicated in the preoperative evaluation of parotid masse ${ }^{11,12}$ since it can furnish the diagnosis, preparing both the surgeon and the patient in the surgical planning. The cytological characteristics in this case were suggestive of Hodgkin lymphoma $(\mathrm{HL})$. Specific cytological descriptions of NLPHL subtype are limited in the literature. ${ }^{13}$

The surgical procedure adopted in the present case permitted the separation of the superficial and deep lobes of the parotid gland from the origin of the facial nerve in order to preserve it. The non-occurrence of salivary fistula neither facial nerve injury showed the appropriate surgical technical option. Intraoperative evidence of exclusive involvement of intraparotid lymph node led to end the surgical procedure with its complete excision and preserving the parotid gland.

The most common treatment for localized NLPHL is the total excision of involved lymph nodes followed by radiotherapy. ${ }^{14}$

None of the most frequent complications after the parotid gland manipulation like facial palsy, Frey's syndrome, salivary fistula, and loss of sensation in the area of the parotid gland occurred in this case. ${ }^{15}$ 
In conclusion, lymphoproliferative disorders are usually not considered in the initial management of a parotid gland mass and are rarely suspected before biopsies or surgical removal. We describe a rare case of nodal NLPHL in the parotid gland, treated with lymph node excision and local radiotherapy with uneventful 5-year follow up.

\section{ACKNOWLEDGEMENTS}

We are grateful to Rosa Maria C. Zanardi for the technical support on the visual work.

\section{REFERENCES}

1. Swerdlow SH, Campo E, Harris NL, et al., editors. WHO Classification of Tumours of Haematopoietic and Lymphoid Tissues. 4th ed. Lyon: International Agency of Research in Cancer; 2008. v. 2, 439 p.

2. Von Stritzky M, Wereldsma JC, Pegels JG. Parotid mass as first symptom of a maligmant lymphoma. J Surg Oncol. 1998;67:25-7. http://dx.doi.org/10.1002/(SICI)1096-90 98(199801)67:1\%3C25::AID-JSO5\%3E3.0.CO;2-O

3. Rosai J. Major and minor salivary gland. In: Rosai J, editor. Rosai and Ackerman's surgical pathology. 9th ed. Edinburg: Mosby; 2004. p. 896-7.

4. Dispenza F, Cicero G, Mortellaro G, Marchese D, Kulamarva G, Dispenza C. Primary Non-Hodgkins lymphoma of the parotid gland. Braz J Otorhinolaryngol [Internet]. 2011 [cited 2012 Feb 29]; 77:639-64. Available from: http:// www.scielo.br/scielo.php?script=sci_arttext\&pid=S180886942011000500017\&lng=en\&nrm=iso http://dx.doi.org/ $10.1590 /$ S1808-86942011000500017.

5. Boring CC, Squires TS, Tong T. Cancer statistics. CA Cancer J Clin. 1993;43:7-26. http://dx.doi.org/10.3322/canjclin.43.1.7
6. Yuen A, Jacobs C. Lymphomas of the head and neck. Semin Oncol. 1999;26:338-45. PMid:10375090.

7. Sohani AR, Jaffe ES, Harris NL, Ferry JA, Pittaluga S, Hasserjian RP. Nodular lymphocyte-predominant hodgkin lymphoma with atypical T cells: a morphologic variant mimicking peripheral T-cell lymphoma. Am J Surg Pathol. 2011;35:1666-78. PMid:21997687. http://dx.doi. org/10.1097/PAS.0b013e31822832de

8. Lee AI, LaCasce AS. Nodular lymphocyte predominant Hodgkin lymphoma. Oncologist. 2009;14:739-51. PMid:19605845. http://dx.doi.org/10.1634/theoncologist.2009-0099

9. Masuda M, Segawa Y, Joe AK, Hirakawa N, Komune S. A case of primary Hodgkin's lymphoma of the parotid gland. Auris Nasus Larynx. 2008;35:440-42. PMid:17983719. http://dx.doi.org/10.1016/j.anl.2007.09.008

10. Yencha MW. Primary parotid gland Hodgkin's lymphoma. Ann Otol Rhinol. 2002;11:338-42.

11. Zapanta PE, Truelson JM, Rosen CA, Meyers AD. Fineneedle aspiration of salivary glands [Internet]. [place unknown]: WebMed Professional, c1994-2012 [updated 2011 May 4; cited 2012 Mar 8]. Available from: http:// emedicine.medscape.com/article/882291-overview

12. Zbären $P$, Schär $C$, Hotz MA, Loosli $H$. Value of fine- needle aspiration cytology of parotid gland masses. Laryngoscope. 2001;111:1989-92. PMid:11801984. http://dx.doi. org/10.1097/00005537-200111000-00023

13. Subhawong AP, Ali SZ, Tatsas AD. Nodular lymphocytepredominant Hodgkin lymphoma: Cytopathologic correlates on fine-needle aspiration. Cancer Cytopathol. 2012 Feb 24 [Epub ahead pf print]. http://dx.doi.org/10.1002/ cncy. 21186

14. Spector N. Abordagem atual dos pacientes com doença de Hodgkin. Rev Bras Hematol Hemoter. 2004;26:35-42. Portuguese.

15. Kligerman J, Lima RA, Dias FL, Barbosa MM, Freitas EQ, Matos de Sá G. Complicações das cirurgias dos tumores das glândulas salivares. Rev Bras Cir Cabeça Pescoço. 2003;(31):55-60. Portuguese.

\section{Conflict of interest: None}

Submitted on: $5^{\text {th }}$ February 2012

Accept on: $25^{\text {th }}$ February 2012

Correspondence: Serviço de Anatomia Patológica

Av. Prof. Lineu Prestes, 2565 - Cidade Universitária - São Paulo/SP - Brazil

CEP: 05508-000 - Phone: +55 (11) 3091-9384

E-mail: patpicciarelli@yahoo.com.br 
